\title{
TOWARD A STANDARD FOR STUDENT ACADEMIC FREEDOM
}

\author{
PhIILIP Monypenny*
}

\author{
A committee of the American Association of University Professors (AAUP) has
} been engaged in an effort to produce a statement on academic freedom for students which might have some of the authority in that field which the 1940 Statement on Academic Freedom has had for university and college teaching. The draft so far produced bears little resemblance to the I940 Statement. It is far longer, far more detailed; it covers many topics, some of which at first glance seem to be only distantly related to conceptions of academic freedom. ${ }^{1}$

One of the questions which comes up early in the general discussion of student academic freedom is implicit in the name of Committee S, "Faculty Responsibility for Student Academic Freedom." Is there a sufficient connection between academic freedom for the teaching staff and for students that faculties have any concern

*A.B. 1936, Washington University; M.A. 1937, Ph.D. 1942, University of Minnesota. Professor of Political Science, University of Illinois. Editor, Midwest Journal of Political Science. Contributor of articles to various journals in the fields of state and local government and political science.

${ }^{1}$ There are some logical implications of the term "student academic freedom" which have not been explored at all, or by omission have been denied. The community of scholars which is postulated is under the control of the senior scholars, the faculty, and the administrators, and the students come to study what these people are willing to teach. In this context, student academic freedom does not mean student control of the content of instruction, the standard of instruction, the selection of staff, or the direction of institutional development. On the other hand, there is an advantage in consulting students about these matters. By their selection of teachers, courses, and curriculum, students do help shape the future of the institutions they attend.

Nor do we belicve that the institution is obligated to provide instruction in every topic from every possible point of view, so that the institution as a whole is value neutral. It is the student's business to explore contrary viewpoints to those expressed in the classroom, and he should be encouraged in that endeavor. In the four years of an undergraduate education in an intellectually competent institution he should be exposed to a considerable variety of viewpoints and should learn to identify the viewpoints, and thus to locate them in the spectrum of possible points of view. We do assert that students should not suffer penalties for the expression of their own viewpoint, nor for refusing to accept the assumptions of their instructors, nor for going beyond the classroom assignment for material to make an argument or test an assertion. They can properly be held to account for knowing the official viewpoint of the classroom, the particular selection of data which is there offered, and the necessary logical consequences of that viewpoint and that data. But knowing or asserting other or more is certainly not to be penalized. If it is, student academic freedom suffers, and academic freedom does not exist.

Nor has the question of admission to educational institutions been examined as it may be limited by race, or status, or otherwise. It is taken for granted that admission should be without prejudice to person, race, religion, or other factor irrelevant to intellectual accomplishment and intellectual promise. It is taken for granted that once admitted, opportunities for learning and evaluation of achievement will be by a single objective standard for all students. It is further taken for granted that institutional facilities of all types will be open to all persons without prejudice, that all citizens are equal who have equal intellectual accomplishment. Thus all institutions and all facilities within institutions, and all activities sponsored by institutions should be open without restriction based on race, religion, nationality, color, and other academically irrelevant consideration. These things are part of student academic freedom, which is a freedom to learn if it is anything; but they are also so much a part of the general standards of our society that it should not be necessary to spell them out in detail in their application to educational institutions. 
whatever for student academic freedom? There are two answers, which are essentially one. First, there is a firm position in the AAUP that faculty members have an important role to play in the general administration of colleges and universities. One of the important and difficult questions in administration is the handling of student discipline and student affairs. A faculty with administrative responsibilities, therefore, must face it. More fundamental is the inherent responsibility of the faculty to use whatever influence it has to maintain a set of conditions in which teaching and learning alike are most effective and most free. The Association is accepting that responsibility of teachers in its current effort to produce a statement on student academic freedom. The faculties of the several campuses must use their influence through the channels available to them to promote and protect students in the areas of freedom which they should have. As the scope for faculty participation in general policy making and administration is greater, they will be in a position to exercise more influence. But even through informal channels they can have influence and it is an inherent part of their responsibility as faculty members to use what influence they have.

The difficulty is that students are essentially in a position of dependence, subject to the authority of the institution from which they hope to receive their degrees, subject to the authority of their teachers whose periodic grading and whose later recommendations to possible employers and sources of assistance for further study determine whether they will achieve the aims which they seek through higher education. There is no way of eliminating that dependence; the certificate of various educational authorities is the necessary condition for the fulfillment of many of their personal goals.

The point at which the committee began in its definition of the place of students in educational institutions was an old and hopefully honored conception: the educational institution is a community of scholars. Presumably the teaching profession as a whole is a community of scholars as are teachers in the various branches of learning and teachers on the various campuses. The connotations of community are a set of common standards developed by the interaction of its members, developed out of shared experience rather than imposed by authority. The development of fields of study, the content and sequence of courses, and the standards which are applied to appointment and promotion of faculty members, are more nearly products of a kind of consensus in the various academic fields than they are expressions of the authority of the administrators in the several institutions. In a few institutions, faculty control of the most deliberate kind infuses the whole administration of the institution. Obviously there is a distribution of institutions between these minima and maxima, but the community of scholars is everywhere a force in shaping the careers of individual teachers and the general course of higher education.

If we bring the student into this context, our obvious purpose as teachers is to 
help him to become a self-directing, responsible person, capable of independent decision in the fields of action which are open to him. We share with him not only our understanding and our knowledge but our experience of gaining knowledge so that he may be capable on a more modest or a more ambitious scale of gaining knowledge on his own. It is not the business of higher education in the United States to train automata. What we would desire for all our students is that they learn the methods and habits of independent thought which are the methods of scholarship. Thus they are less students in the sense of persons in a wholly passive and subordinate intellectual position than scholars-in-training. As scholars in training they are apprentice or junior members of the scholarly community.

Once we have brought the student into the community of scholars then a number of things become clear. $\mathrm{He}$ is to be given opportunities for independent thought and independent action in a somewhat protected environment so that he will be capable of independent thought and action later as a full member of the adult community. As teachers we are concerned primarily with his activities as a scholar and only secondarily with other activities, as they affect the conditions of learning in the academic community of which he is a part. Thus some of the principal grievances of students are matters of much less concern to us than they are to the students. We do not need to inquire into the merits of beer being served in the campus union, whether or not there are hours when students must be in their dormitories, or what requirements for class attendance are set up. Only in a remote way do these things affect the primary job of learning. In all decisions about student life, however, we are in the standard position of a parent dealing with a young adult: we wish to provide some protection against the possible consequences of independent action, while still providing conditions which encourage the exercise of independent judgment.

In developing a draft statement the committee was forced to deal with a number of topics to all of which the basic conception of the academic community was relevant. On a few topics, other conceptions play a part but happily they reinforce rather than contradict the conclusions which might be reached from the major premise alone.

The first topic which one encounters in thinking about academic freedom for students is the standard constitutional categories, freedom of speech, assembly, petition, publication, and, possibly, religion. They are not as obvious as they seem. If students are only dependent persons subject to institutional authority they would have only such rights in these areas as the university or college administration thought fit for them to have.

In our own thinking such rights are basic conditions of scholarship, therefore basic conditions of any educational enterprise. Since we are training people for independent thought by giving them occasion for thought and opportunities for expression of thought, the whole campus, and not just the classroom, must provide 
appropriate conditions. Indeed, the classroom alone is heavily under the weight of the teacher's authority, both as an institutional representative and as an established scholar, so that independence of thought is to be pursued as much outside of it as in it. Therefore, restrictions on speeches and speakers on campus, restrictions on meetings and topics of discussion, on the distribution of leaflets and pamphlets, on demonstrations of sentiment and conviction by picketing and parading, are unacceptable except as they are necessitated by the protection of instructional activities from disturbance, by the minimum requirements of safety, orderly traffic, and the protection of property against misuse. It is true that the intellectual content of these activities is largely limited to the various issues of public policy which currently agitate students, but it is in the context of a self-governing society that all of our scholarly traditions have developed. None of us, whatever his scholarly field, can escape the responsibility for participating in the decisions of the great questions about the character of human life which lie behind the current topics of political discussion. It is just such topics that stretch the intellectual competence of individuals to the utmost, since they cannot be handled by any neat pattern of established scientific principle.

Freedom of expression for students is both simplified and confounded by the fact that the rights of which we are speaking are protected against government and by implication against the educational agencies of government such as the public institutions of higher education. Whether private institutions which have governmentally granted charters, the benefits of tax exemption, and various kinds of governmental subsidies, are similarly obligated to observe constitutional rights is beyond the limits of this article. What is important is that the rationale of freedom of speech and its concomitants for students is the same whether in public or private institutions, though in one it may have some protection as a constitutional right which it does not have in the other. We must not be misled into assuming that where there are no legal rights there is no obligation to observe restraints on institutional authority.

The parallels of constitutional liberties which should exist for students on campuses are not easy for all administrations to accept, since the view is still strong, even in public institutions, that educational institutions are essentially proprietary enterprises whose owners and managers have the right to determine what to do with their property and whose good name is bound up with the uses to which it may be put. The only rejoinder is that the legal rights of ownership are an insufficient basis for determining what policies should be put into effect in an educational institution. If it is to achieve its purpose as an educational enterprise, then it must observe the conditions which its educational purpose requires. As we have said, the basic assumption which we make is that in higher education the conditions are best summed up by regarding the educational enterprise as a community of scholars devoted to the discovery and propagation of knowledge. Those persons 
who have the legal responsibility for the creation of such a community best fulfill their responsibilities by giving its educational processes the largest measure of autonomy that they can.

There are questions in this area of freedom of expression to which we will return later. Setting out the other areas of concern, students are not only citizens of a campus community under various obligations defined by those with legal control over them. They are also citizens of the larger world with opportunities and obligations thereof. The disciplinary powers of college or university may be used to stifle expression off campus as well as on campus, and this has happened when university sanctions are imposed in addition to the civil sanctions which the student faces in some of his off-campus activity which comes into conflict with the law.

It is doubtful whether even ordinary criminal offenses off campus should carry any automatic academic penalty. The particular concern of the scholarly community is offenses against scholarship and against the conditions of scholarship. Being drunk and disorderly on Saturday night is likely to impair a man's capacity for study if repeated often, but there are civil authorities well equipped to deal with that sort of offense. Unless the student prefers to be released to institutional discipline, it would seem to promote maturity to let such offenses be a private matter between the student and civil authority. Even in the case of more serious crimes, the concern of the educational institutions with future possibilities rather than with present deficiencies argues for care in deciding what sorts of offenses constitute academic disabilities.

Compared with some other questions, however, these are relatively easy situations to handle, since ordinary criminal offenses do not produce the widespread interest and passion which other engagements with the law do. The most difficult conflicts of students with civil authority have a political basis. Participation in demonstrations of all types with respect to race, peace, nuclear disarmament, and refusals to testify before congressional investigating committees with respect to political beliefs or activities, have brought thousands of students into conflict with the law. In some communities the pressure to add institutional sanctions to whatever civil sanctions the student has incurred is very strong. In some cases, as in the public Negro colleges in some southern states, the very survival of the institution may be at stake. Yet it is obvious that the university or college does not serve an educational purpose by using its disciplinary powers to dissuade students from participating in the political protests of their time. The existence of strong emotions and great hostility only underlines the need for the campus to follow a different and less restrictive set of standards than the community at large is able to maintain.

The other uses of the powers of university and college authorities over students and their activities concern the scope and sanctions of controls of on-campus conduct outside of the classroom, the extent and structure of student government, the management of student publications, the definition and punishment of strictly 
academic offenses such as plagiarism and cheating, and the compilation and release of information about students, other than the official transcripts of courses and grades. These are discussed more briefly, and we then return to more general questions.

In the case of on-campus offenses, other than those which arise out of institutional efforts to control freedom of expression in its various forms, the problems are more nearly those of due process than of substantive rules. Any educational institution imposes elaborate restraints upon students: they must take certain sequences of courses; they must keep their marks up to a given level; they must not cheat in the performance of their academic tasks; they must return library books on time and not deface them; they must maintain order in their residence halls and not deface property; they may be required to maintain curfews of various sorts; they may be subject to regulations as to dress, and subject to restrictions on smoking and drinking and propriety in overt sexual behavior. None of these in our view per se violates student academic freedom, since they are incidental to learning activity, and serve to protect and promote it rather than to inhibit it if kept in reason. Preferences, depending on educational philosophies and theories of human development, will vary as to what kind of regulations should be imposed on students outside the classroom.

What is important in developing a national standard is that the existence of student failings which may warrant the imposition of sanctions should be determined in an orderly way which provides the usual guarantees of due process and protects the student against malice, arbitrariness, and oppression. Legal limitations have been imposed by some courts on educational institutions when degrees are withheld for reasons which seem to those courts to be insufficient. This undoubtedly reflects the tremendous power which educational institutions have come to exercise over the futures of individuals in a society in which formal higher education is a necessary prelude to almost every kind of occupation which provides a comfortable income or desirable social status. It means that the decisions of the teacher that there has been abuse of academic standards of propriety sufficient to warrant failure in a course, or to put a student in jeopardy of dismissal from the institution, must be subject to appeal to other authorities and to an orderly process of inquiry and decision by impartial judges. What is true of academic offenses is true also of others-allegations of stealing, destruction of property, questionable sexual behavior, and so on. The institution should have a wide latitude in the definition of the offense, but it should be held to a scrupulous standard of proof whenever major sanctions are to be imposed.

With these serious matters in view, the character of student government may seem like a very minor matter. It warrants some discussion, however, because it contributes to the general impressions which students develop about their relation to the institution, and the sense of security or insecurity with which they regard 
the disciplinary powers of authorities. Student government is virtually universal, though the scope of its activity is quite diverse. Only in exceptional cases would it seem to have more to do than to play a minor part in the control of extracurricular activities, the allocation of revenues among student activities, and to make recommendations on codes of student affairs. It would be impossible to make a national prescription as to student government in the endless variety of institutions in the United States. The principles we are developing suggest that student government should have at least a consultative role in the development of a code for student affairs, including the definition of punishable offenses, and the scale of punishments; that student representatives should sit on the disciplinary tribunals which consider student offenses; and that control and administration of extracurricular activities should be largely in their hands. Even more important than setting out minimum areas of student self-determination is the principle that whatever charter is set up should not be subject to unilateral abrogation by university or college administrative officers and that the decisions of student-governing organs should not be subject to unilateral abrogation by college authorities. To do otherwise is to display an arbitrariness which is the very opposite of the defined areas of free initiative which we are asserting to be the necessary conditions of sound education.

Student publications raise problems which bring into play the rights of freedom of expression with which we began. Our general principle is that freedom of discussion on the campus should be uninhibited. This means that student organizations should be free to invite speakers without prior authorization as to speaker or topic. Clearance for the use of space and the avoidance of conflict with other public events is reasonable if it is not used as a device to provide an indirect veto. It means that student meetings, discussions, orderly parades, picketing and other forms of demonstration should be free of control or advance permission, other than for reasons of orderliness which apply also to speakers.

In this context student publications should enjoy a similar freedom of publication without advance censorship or subsequent sanction because of faculty disapproval of content or style of expression. There are difficulties in this area because student publications are often subsidized or paid for by compulsory activity fees and have a monopolistic position vis-à-vis their readers. On the other hand, to make them semi-official organs for approved opinion is to seriously limit their educational function. The student editorship and management should have the same freedom as their professional counterparts. They are appointed for a term and conceivably may fail of reappointment if the managing board does not approve of their use of their offices. Since editors in the general press operate under the same limitation, this is not to depart too far from life. On the other hand, the board should be representative of student, not faculty or administrative opinion, and the members of the 
board should not be subject to removal before the expiration of their terms because someone disapproves of their use of their discretionary powers.

Some of the most acute situations with respect to student publication arise not in the field of political opinion but with respect to religious doctrines in church related schools. Since one of the purposes is to prepare persons for leadership in the church, both lay and clerical, doctrinal questions are important to students, faculty, administrators, and governing bodies representing the denominational group. The case for independent thought and expression would seem to be as good here, however, as it is on political questions, if the individual mind and conscience are believed to be the testing ground for religious truth.

Religious affiliation of institutions of higher education which offer primarily secular training creates still other problems in the field of student discipline. The faculty and administration of such a school may exercise pastoral as well as academic authority over those students who are members of the faith of the sponsoring church. Thus the line between the external conduct of students and their conduct at the institution tends to vanish, at least in the areas which church authorities regard as matters of faith and morals. Offenses against ecclesiastical regulations may carry not only the usual religious penalties but academic sanctions such as dismissal from the school. A well publicized case at a Long Island institution in which members of the senior class participated in a civil marriage contrary to church regulation ended in the expulsion of several participants, including the witnesses to the civil ceremony. The married couple were later married by approved rites. This is an extreme case of the joining of academic and religious discipline for the same offense and in the same authorities. It is to be regretted. Members of the church who attend institutions of higher education administered by the church are put under greater penalties than are members of that church who pursue higher education by other means or who do not pursue it at all. The penalties for nonconformity are heightened by an institution of higher education rather than relaxed in order to achieve an educational end. Committee $S$ proposes no position such as use of ecclestiastical authority within an institution of higher education, but its occurrence underlines the complexities of the student's relationships to the institution which he attends and the various ways in which his state of dependence may be reinforced.

Another acute area is literary publications, often more directly and completely controlled by faculties within the educational institution than are student newspapers. The troublesome questions have to do with obscenity and taste. The enthusiasm of young people for exploring subject matters and styles of expression which their elders find to an equal degree boring and devoid of taste is unending. Educationally the values seem to lie with exploration and free publication rather than control, trusting to the good sense of readers and editors to correct excesses. No one can be sure of swimming who has not been in the water. College students 
are very close to being adults with adult responsibility and opportunity to make their own choices both in literature and in action. College literary publications can scarcely add anything to the literary environment which is not there already and students had better to learn a standard of literary taste by operating their own publications and criticizing the work of their fellows than by attempting to deal with the bewildering output of meretricious stuff available to them from commercial sources.

The principal source of difficulty in the field of student publication is the assumption that because it is a student product the college or university is in some manner responsible for it and will suffer if publications offend their readers. This in turn rests on the assumption that the university or college should, will, and can control such publications. If it is clear that students act on their own responsibility, only the most bigoted can insist on institutional responsibility. It is against such bigots that a worthy educational institution must continually assert its primary obligation to discover and to propagate knowledge whatever the discomfort that it causes. Student freedom in intellectual and literary matters is one of the conditions of realizing that obligation.

To all too many people educational institutions are primarily agencies for inculcating the habits and values that will continue the kind of society which they find comfortable. Any social scientist will recognize that this is in fact an important function of any educational institution. However, educational institutions have never been only this: they are also places at which innovative behavior may develop, in which the accommodations to changing conditions may be tested, in which the knowledge which creates new possibilities of action may be won. Considering the long term of human affairs, this last aspect is quite as important as the former. A society which provides only for the former can scarcely hope to overcome the perils inherent in life itself. The most important principle of any educational enterprise is that not all is known that can be known or should be known and that guides out of the past are, therefore, always insufficient for the future. The arguments which rest on the simple protection of the past, as do most arguments for the imposition of authority as against the stimulation of independent thought, are therefore fallacious guides to decision, whether in education or in other matters.

If educational institutions are to serve the functions which we postulate, then they must be a community in which ideas can develop, be exchanged, tested, and discarded, in which the unorthodox is given a hearing and in which the inhibitions against the new and strange are at a minimum. Such a community cannot be a community of teachers only, since the most important product of teachers is their students. Their students can have the advantage of the characteristic experience of the community, of free intellectual innovation and exchange, only by participating in it. Their participation must include not only the formal educational process but also activities which arise spontaneously out of student enthusiasms and concerns. 
So we have run the full circle, and each of the particulars fits at some point within it.

There is a footnote to this discussion which may cause more trouble when the committee draft circulates for general discussion than it has so far caused within the committee. It is conventional to postulate the issues which affect student rights in a context of a sort of joint student-faculty resistance to administrative oppression. I doubt if the students see it that way. In fact, the notion that academic freedom for faculties is something which concerns students because it affects the kind of education they are likely to have is only just now beginning to penetrate the ranks of students themselves, and to some it is obviously an uncomfortable idea. The members of the faculty in their capacity as teachers, not only in their capacity as members of the administration through committees and governing councils, dispose of considerable restrictive power. The first penalty for unorthodoxy which a student encounters may be a painful rebuke for a classroom expression. It is no less a penalty because the unorthodoxy of the classroom may be orthodoxy in the context of the student's life outside. Students may suffer lowered grades not only for incorrect reasoning but for unacceptable conclusions. More routinely, the decisions as to standards of performance and their application to individual students are among the most firmly established prerogatives of faculty members. Nevertheless they pose questions of justice and equity on which there should be an appeal when there is a prima facie evidence of error or injustice. This is especially so in the instance mentioned earlier-the charge of cheating, plagiarism, or other academic impropriety-which is often made informally and enforced by a low or failing grade given ex parte and without notice.

In another relationship also the teacher has a considerable power over his students and is even less accountable. In the increasing reliance upon authority to establish personal integrity for various purposes, teachers are appealed to by governmental agencies, employers, other institutions, and even bar associations for testimonials as to character. Such testimonials are willingly given, but they do put the student's reputation at the hazard of a communication which he never sees, of whose existence he may never know. The situation is compounded by the existence of deans of students, security officers, counseling offices, and others who compile "personnel records" quite apart from official transcripts, potentially available to document judgments as to temperament, character, and other not strictly academic attributes. Some students have expressed the fear that expressions in class, on term papers, in examinations, or office conferences, may be held against them or used indiscreetly in some of the inquiries which come to administrators and faculty members alike. Since academic institutions in their own recruitment are among the most active seekers after such informal testimony as to character and talent, it is hard for them to refuse to countenance its use by others.

Nevertheless, the teacher clearly has an obligation which is part of student 
academic freedom not only to deal fairly with students but to be a safe repository of confidences and of knowledge willingly or unwillingly acquired which may damage the student's future more than its revelation would damage the nation's or any institution's security. For the institution itself, there are very serious questions as to what records about students, other than those built up in official and formal proceedings, it should either originate at all or keep beyond the years of the student's attendance. The instantaneous possibility of communication and the electronic capacity to sort and collate data have made the miscellaneous records of a lifetime a source of more potential danger to all of us than was the case in a simpler world in which one's college transcript quietly mouldered in the recorder's vault once the years of one's attendance were over. The past may be forgiven by some, but it is never forgotten under these conditions; it is always available to the malignant and the implacable. Whether communities of scholars can flourish under such conditions is a still-to-be-established proposition. Certainly every teacher must ask himself whether the information at his disposal about students must not be guarded as carefully against unnecessary disclosure as are the physician's knowledge of his patients, the clergyman's knowledge of his parishioners, or the lawyer's knowledge of his client's affairs.

The field of the academic freedom of students is thus a comprehensive field because the student is so much more thoroughly immersed in the life of the institution and so much more dependent on it than even is the faculty member. The areas of student freedom, which are areas of self-limitation by institutional administrators and by faculty, are correspondingly complex in their configuration and harder to define. Yet the stakes are essentially the same. The only knowledge which is worthwhile in the end is the knowledge of how to gain knowledge for the purposes for which one needs it and how to employ it in judgments about difficult questions. For that knowledge to be gained there must be substantial areas of free thought not only for faculty members but also for students. If Gedanken sind frei, as the German folk song has it, and silent thought is without penalty, expression-oral, written, or by public demonstration-arouses deep antagonism and brings forth cruel penalties even in the most civilized societies. It is to the area of expression that we must direct our standards and it is in the latter area that the worth of our colleges and universities as educational enterprises will be tested. 